\title{
降水和植被变化对径流影响的尺度效应 以陕北黄土丘陵沟壑区为例
}

\author{
丁婧袜 1 , 赵文武 ${ }^{19}$,王军 ${ }^{2}$,房学宁 1 \\ (1. 北京师范大学资源学院, 地表过程与资源生态国家重点实验室, 北京 100875 ; \\ 2. 国土资源部土地整治重点实验室, 北京 100035)
}

\begin{abstract}
摘 要: 自黄土高原退耕还林还草政策实施以来,在水源涵养功能明显提升的同时径流显著减少,导致该区域出现 了水源涵养服务与水供给服务间的权衡问题。为探究径流减少的原因,进而为不同空间尺度的生态系统服务权衡 提供支撑, 本文分析了陕北黄土丘陵沟壑区 2006-2011年降水和植被变化对径流影响的尺度效应。结果表明: 研究 区域内汛期降水量呈现出由东南向西北逐渐减少的空间分异特征; 在研究时段内, 植被恢复效果明显, 近 8 成地区 植被覆盖状况得到了改善, 尤其是植被覆盖较差的地区恢复效果更为显著; 在各子流域中, 降水与径流间呈现出显 著的正相关性, 二者的相关系数随着子流域面积的增加而增大, 表现出明显的尺度效应。随着子流域面积增大, $15^{\circ}$ 以上土地比例增加, 陡坡植被覆盖类型趋于均一化, 具有显著截流功能的林地呈现减少趋势是尺度效应形成的 主要原因。NDVI 与径流的相关性不显著, 二者的相关系数随着子流域面积变化的规律性不强, 植被对径流影响 没有明显的尺度效应。
\end{abstract}

关 键 词:NDVI; 降水; 径流; 尺度效应; 权衡; 黄土丘陵沟壑区

\section{1 引言}

径流是人类生产生活用水的主要来源, 也是水 资源合理开发利用、优化配置的基础。径流变化受 气候、地貌、土壤、植被以及人类活动的共同影响 (Appels et al, 2011; Huza et al, 2014; Lei et al, 2014; Zhao et al, 2014)。其中降水是影响径流的主要因 素, 雨量大小直接影响径流量的多少, 且雨滴通过 对地面的打击和溅散作用会对土壤结构和产流过 程产生影响(Hammad et al, 2006)。在流域、区域尺 度上, 往往基于水文站点、气象站点的长时间序列 数据分析降水与径流的关系。多数研究表明, 在时 间序列上降水和径流的波动趋势一致, 二者具有良 好的正相关性(Kirkby et al, 2005; 董晓辉等, 2007;
Chang et al, 2010; Mayor et al, 2011)。除降水以外, 植被也是影响径流的重要因素。在降雨过程中, 植 被地上部分主要通过冠层截留等过程对降雨进行 再分配,地下根系则通过改变土体构型, 增强土壤 的人渗能力等影响径流的产生(傅伯杰等, 2010; 艾 宁等, 2013; 高光耀等, 2013; Kim et al, 2014)。目 前, 在流域、区域尺度上往往用归一化植被指数 (Normalized Difference Vegetation Index, NDVI) 代 表植被覆盖状况(李双双等, 2012), 从时间尺度上分 析植被对径流的影响。相关研究结果显示, NDVI 与降水的相关性较好, 但与径流的关系较为复杂, 在不同地区二者间的正负反馈机制有所差异(孙睿 等, 2001; 李春晖等, 2004; Onema et al, 2009; Mao et al, 2012)。

收稿日期: 2014-11; 修订日期:2015-04。

基金项目: 国土资源部土地整治中心开放课题项目(2015-01-62); 国家自然科学基金项目(41171069)。

作者简介: 丁婧神(1993-), 女, 河南许昌人, 硕士研究生, 主要从事土地利用与生态水文过程等方面研究,

E-mail: jyd2104011510@163.com。

通讯作者: 赵文武(1976-), 男,山东曹县人,副教授,博士生导师,主要从事景观格局与生态系统服务、生态水文过程研究,

E-mail: zhaoww@bnu.edu.cn。

引用格式: 丁婧神, 赵文武, 王军, 等. 2015. 降水和植被变化对径流影响的尺度效应: 以陕北黄土丘陵沟壑区为例[J]. 地理科学进展, 34(8): 1039-1051. [Ding J Y, Zhao W W, Wang J, et al. 2015. Scale effect of the impact on runoff of variations in precipitation/vegetation: taking northern Shaanxi loess hilly-gully region as an example[J]. Progress in Geography, 34(8): 1039-1051.]. DOI: 10.18306/dlkxjz.2015.08.011 
尺度是自然界固有的本质特征 (邱扬等, 2004)。在景观生态学中, 尺度是指某一现象或过 程在空间或时间上所涉及的范围和发生的频率, 通 常用粒度和幅度来表示(邬建国, 2000)。格局和过 程是景观生态学研究中的经典范式, 由于地球系统 的等级性和复杂性, 不同尺度的景观格局和生态过 程可能大不相同, 单一尺度上的研究结果往往不能 直接应用于其他尺度, 这种格局和过程依赖于尺度 的特点即为尺度效应 (吕一河等, 2001; Dungan et al，2002; 赵文武等，2002; Wu，2004; 傅伯杰等， 2010)。流域是以水文站点为出口的地面水和地下 水天然汇集区域,是研究生态过程的基本单元。不 同面积大小, 即不同空间幅度的流域, 其土地利用 结构、景观格局具有明显差异。降水、植被对径流 影响的机制往往会随着流域面积的变化而发生变 化(张志强等, 2006), 呈现出明显的尺度效应。目 前, 关于降水、植被对径流的影响研究主要集中于 某一小流域或大流域上(傅伯杰等, 2002; 赵文武 等, 2004; Bi et al, 2009; 刘海猛等, 2013)。而关于不 同尺度流域降水和植被对径流的影响研究相对较 少(綦俊谕等, 2011), 探讨尺度效应产生机理的研究 更少。

陕北黄土丘陵沟壑区是中国乃至全球水土流 失最严重的地区之一(Shi et al, 2000)。自 1999年 起, 中国政府开展了退耕还林还草工程。19992004 年期间, 黄土高原植被覆盖度显著提高, 水土 流失状况得到了明显控制, 区域生态系统的水源涵 养功能得到了有效提升(张宝庆等, 2011)。2004年 以后, 退耕还林还草工程从规模扩张型向质量效益 型转变, 其工作重点放在巩固成果、规范管理和生 态可持续发展等方面(王闰平等, 2006)。然而,在生 态恢复成效显著的同时, 黄土高原地区的径流量也 明显减少(刘晓燕等, 2014), 影响了当地以及黄河下 游居民的生产生活, 导致在该区域出现了水源涵养 服务与水供给服务之间的权衡问题。降水和植被 是影响径流的两个重要因素,在不同面积流域上探 究降水和植被变化对径流的影响及其尺度效应, 有 助于为不同流域尺度的生态系统服务权衡提供依 据。本文以陕北黄土丘陵沟壑区 13 个典型子流域 为研究区, 选取退耕还林还草工程进人质量效益型 阶段的 2006-2011 年为研究时段,利用 13 个子流域 5-10月的降水、植被和径流等数据, 系统分析了区 域降水和植被的变化特征, 探讨了不同空间尺度降 水和植被对径流的影响及其尺度效应, 以期在丰富
尺度效应研究案例的同时,为制定该区域不同尺度 生态系统服务权衡策略提供科学支撑。

\section{2 数据与方法}

\section{1 研究区域概况}

陕北黄土丘陵沟壑区位于 $108^{\circ} 45^{\prime} \sim 110^{\circ} 25^{\prime} \mathrm{E}$ 、 $36^{\circ} 10^{\prime} \sim 37^{\circ} 55^{\prime} \mathrm{N}$ 之间, 包括延河流域、清涧河流域、 汾川河流域和无定河流域中的大理河流域,主要涉 及延安、延长、安塞、子长、清涧等县市, 总面积 $17488 \mathrm{~km}^{2}$, 共有水文站点 13 个, 雨量站点 102 个。 该地区处中国东部季风湿润区与内陆干旱区的过 渡地带, 植被呈现出从东南向西北由阔叶林向森林 灌木草原过渡的特点。境内丘陵起伏, 沟壑密布, 地表支离破碎。水土流失面积占总面积的 $90 \%$ 以 上, 是黄河中游水土流失最严重的地区(图 1)。

\section{2 数据来源与处理}

(1) 本文所用植被覆盖数据来自比利时佛莱芒 技术研究所(Flemish Institute for Technological Research, Vito) 发布的 10 日最大值合成 SPOT-VGT NDVI数据, 空间分辨率为 $1 \mathrm{~km} \times 1 \mathrm{~km}$; 时间尺度为 2006-2011年。由于 5-10月是陕北黄土丘陵沟壑区 植被生长季, 在此期间植被覆盖变化明显(王宏等, 2007; 信忠保等, 2009), 因此选取每年 5-10月的 NDVI数据, 利用以下公式求得:

$$
N D V I=D N \times 0.004-0.1
$$

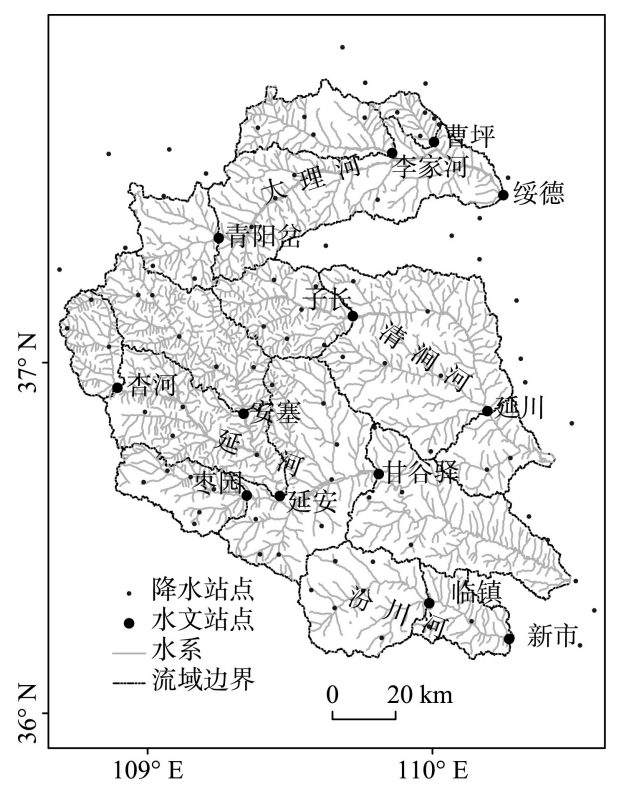

图 1 研究区域图

Fig.1 The study area 
将 SPOT-VGT 的遥感影像像元亮度 $(D N)$ 值转 化为对应的 $N D V I$ 值, 范围为 $[-1 \sim 1]$, 精确到小数点 后两位。为消除云、大气、太阳高度角等部分干扰, 保证 NDVI 反映的是每月地表植被覆盖状况。通过 ENVI 5.1 对每月上、中、下旬的 NDVI数据进行最大 值合成法处理, 得到当月的 $N D V I$ 值。公式为:

$$
N D V I_{i}=\max \left(N D V I_{i j}\right)
$$

式中: $N D V I_{i}$ 是第 $i$ 月的值, $N D V I_{i j}$ 是第 $i$ 月第 $j$ 旬的 值。以 13 个水文站点为把口站, 在 ArcView 3.3 软 件支持下, 将研究区域划分为 13 个子流域, 利用 ENVI 5.1 分别计算 13 个子流域逐月平均 $N D V I$, 然 后以子流域为单元进行统计分析。

(2) 本文所用降水和水文数据来自《中华人民 共和国水文年鉴黄河流域水文资料黄河中游区上 段(河口镇至龙门)》。5-10月是植被生长季同时也 是降水和径流集中的时期(王毅荣, 2005),经计算, 研究区内 5-10月的降水量占全年的 $72.98 \%$; 且由于 部分降水和水文站点是汛期站, 仅记录了 5-10月的 降水、径流数据,因此选择 2006-2011 年的 5-10月 (汛期)的降水和径流数据作为研究数据。通过比较 几种常用插值方法的预测误差、平均标准差、均方 根预测误差和标准均方根预测误差, 选择前三项较 小、第四项接近 1 的普通 Kriging 插值方法, 求得陕 北黄土丘陵沟壑区逐月降水量 Grid 图, 统计得到 13 个子流域 2006-2011 年 5-10月逐月平均降水量。

(3) 本文所用 DEM 数据源于国家基础地理信 息中心的 $1: 5$ 万数据库, 栅格大小为 $25 \mathrm{~m} \times 25 \mathrm{~m}$ 。利 用 ArcGIS 10.2 中 3D Analysis 的 Slope 模块对 13 个 子流域的坡度进行提取。由于黄土丘陵沟壑区地 形破碎, 基于 ArcGIS 提取的坡度并非当地的真实 坡度, 直接使用将产生较大的误差(汤国安等, 2001; 刘欣欣等, 2013), 本文采用汤国安等提出的 坡度转换图谱方法对所提取的坡度进行修正。该 转换图谱是基于典型的黄土丘陵沟壑地貌类型区 获得的, 平均纠正率在 $90 \%$ 以上,适用于黄土高原 该地貌类型区坡度数据的纠正(陈燕, 2001; 汤国安
等, 2001)。通过遥感解译 TM 影像获得 2008年 1:10 万土地利用图。基于坡度图以及土地利用类型图 通过栅格计算提取 13 个子流域不同坡度的土地利 用比例。

\section{3 研究方法}

(1) 趋势分析

一元线性回归分析可以用来分析每个栅格点 的变化趋势, 以单个像元时间变化特征反映整个空 间变化规律和区域时空格局演变(Stow et al, 2003; 马明国等, 2006; 李双双等, 2012), 因此本文采用一 元线性回归分析的方法对研究区域 6 年来 $N D V I$ 的 变化趋势进行分析。

$$
\text { Slope }=\frac{n \times \sum_{i=1}^{n} i \times N D V I_{i}-\left(\sum_{i=1}^{n} i\right)\left(\sum_{i=1}^{n} N D V I_{i}\right)}{n \times \sum_{i=1}^{n} i^{2}-\left(\sum_{i=1}^{n} i\right)^{2}}
$$

式中: Slope 为像元 $N D V I$ 回归方程的斜率, $n$ 代表年 跨度, $i$ 代表 1-6 年的年序号, $N D V I_{i}$ 代表第 $i$ 年的 NDVI值。若Slope 值为正, 表示随时间变化植被指 数升高, 区域植被覆盖存在增加趋势, 且数值愈大 植被覆盖增加趋势愈明显; 反之, Slope 值为负, 则 表示随时间变化植被指数呈下降趋势。

为了更好地评价研究区植被恢复状况, 参照已 有研究(张文帅, 2014), 将 Slope 分为以下 7 个等级: 严重退化、中度退化、轻微退化、基本不变、轻微改 善、中度改善、明显改善(表 1)。

\section{(2) 统计分析}

本文采用统计学中的相关分析法和回归分析 法进行分析。利用 SPSS 19.0 进行相关分析,计算 每个子流域降水与径流、NDVI 与径流的 Pearson相 关系数、偏相关系数, 以及 $N D V I$ 与降水的 Pearson 相关系数,采用 $T$ 检验方法进行显著性检验。并通 过回归分析法拟合降水一径流相关系数、植被一径 流相关系数随子流域面积变化的线性趋势线,分析 降水和植被对径流影响的尺度效应。

表 1 植被覆盖变化趋势分类标准

Tab. 1 Classification standard for vegetation coverage change

\begin{tabular}{cc||cc}
\hline 程度 & NDVI变化趋势 & 程度 & NDVI变化趋势 \\
\hline 严重退化 & Slope $\leqslant-0.0150$ & 轻微改善 & $0.0009<$ Slope $\leqslant 0.0075$ \\
中度退化 & $-0.0150<$ Slope $\leqslant-0.0075$ & 中度改善 & $0.0075<$ Slope $\leqslant 0.0150$ \\
轻微退化 & $-0.0075<$ Slope $\leqslant-0.0009$ & 明显改善 & Slope $>0.0150$ \\
基本不变 & $-0.0009<$ Slope $\leqslant 0.0009$ & & \\
\hline
\end{tabular}




\section{3 结果与分析}

\section{1 降水和植被时空变化}

\subsection{1 降水和植被年际变化}

从年际变化上来看, 各个子流域汛期降水量的 波动特征相似(图 2a)。研究时段内, 2007、2009、 2011 年为峰值, 2006、2008、2010 年为谷值。除临 镇、新市、杏河、束园以外, 其他子流域汛期降水量 均呈波动下降态势, 其中下降最快的是延川子流 域,汛期降水量以每年 $17.31 \mathrm{~mm}$ 的速率减少。因此 从研究区整体来看, 大部分地区汛期降水量随年份 波动下降, 这与黄土高原降水变化趋势的研究结果 一致(刘引鸽, 2007; 王麒翔等, 2011)。

用年最大 $N D V I$ 代表当年植被覆盖状况, 通过 其年际变化来表征 2006-2011 年区域植被覆盖变化 趋势(图 2b)。研究时段内 $N D V I$ 呈小幅度波动, 6 年 内大致经历了以下 4 个阶段: (1)2006-2007年 NDVI 降低; 22007-2008 年 NDVI增加, 基本恢复至 2006 年水平;32008-2009年大部分地区 $N D V I$ 小幅度升 高, 其中延河流域以及汾川河流域的延川、麥园、临 镇、新市子流域 $N D V I$ 有所下降; (4)2009-2011年,除 青阳岔、延安、延川、杏河、安塞子流域在 2010 年 $N D V I$ 有所下降以外, 大部分地区 $N D V I$ 在 20092010 年保持基本不变或略有上升。其中, 2007 年降 水量较高但 $N D V I$ 却明显下降, 表明陕北黄土丘陵 沟壑区退耕还林还草后, 植被状况并不稳定(易浪 等, 2014),在一些年份(如 2007 年)会出现植被覆盖 偏低的现象。而在 2008 年以后, 大部分地区植被恢 复效果较为稳定, 植被覆盖状况保持在一个较高水 平,为区域水源涵养功能的恢复提供了基础。

\subsection{2 降水和植被空间变化}

为表征降水的空间分布情况,计算研究区域内 102 个降雨站点的年平均汛期降水量, 通过普通 Kriging 插值方法得到研究区域年平均汛期降水量 的插值图(图 3)。由图 3 可知, 以绥德西部、麥园东 部以及延安、安塞南部为中心形成降水的极小值区 域, 以临镇、新市周边及子长北部为中心形成降水 的极大值区域。其中研究区内年均最小汛期降水 量为 $399.73 \mathrm{~mm}$, 出现在大理河的绥德子流域; 最大 汛期降水量为 $517.60 \mathrm{~mm}$, 出现在汾川河的临镇子 流域。 4 个流域按汛期降水量大小排序依次为: 汾 川河>清涧河>大理河>延河。该区年平均汛期降水 量总体呈现出由东南向西北递减的空间分异特征。

以每年 5-10月最大 NDVI代表当年植被覆盖情 况,来表征陕北黄土丘陵沟壑区 2006-2011 年植被 变化的空间格局(图 4)。从图 4 可以看出,年均最大 $N D V I$ 整体上呈现出由东南向西北减小的特征。这 与该区域由东南向西北降水逐渐减少,植被类型由 阔叶林向森林灌木草原过渡有关。

基于一元线性回归趋势分析和表 1 的植被覆盖 变化分类标准,得到 2006-2011 年间研究区植被变 化趋势(图 4b)。植被呈退化态势的区域比重为 $20.44 \%$, 其中有 $15.18 \%$ 的区域属于轻微退化, 集中 分布于苯园、延川子流域以及延河流域、清涧河流 域的东南部。由于近年来降水呈减少趋势(李双双 等, 2012), 加之退耕还林还草前期未考虑生态系统 的承载力和植被的适宜性而大量种草植树, 导致植 被覆盖状况在短期内达到较高水平, 但在长期则出 现了轻微的退化现象, 影响了生态系统服务功能的 可持续性(Chen et al, 2008)。植被覆盖基本不变的
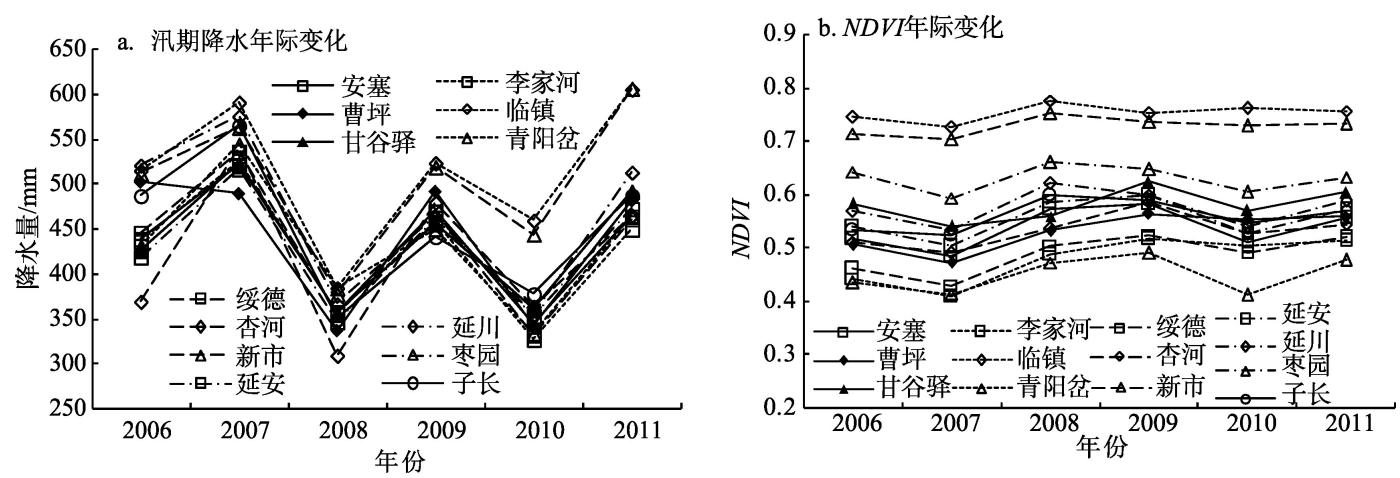

图 2 2006-2011 年陕北黄土丘陵沟壑区不同子流域汛期降水、NDVI年际变化

Fig.2 Interannual variation of flood season precipitation and NDVI of sub-watersheds in northern Shaanxi loess hilly-gully region, 2006-2011 
区域比重仅为 $6.39 \%$, 零星分布于延河流域和清涧 河流域。轻微改善和中度改善区域所占面积比例 较大, 分别为 $30.21 \% 、 27.13 \%$, 连片分布于各子流 域。植被状况明显改善地区占 $15.83 \%$, 集中分布于 大理河流域。由于 2004 年后退耕还林还草工程向 质量效益型转变, 政策调整使得 “造林还草”速度相 比前期增幅有所减少, 但是通过“成片造林、补植补 造、现有培育”等措施植被质量明显提升。研究区 内近 8 成地区的植被得到改善, 这为生态系统恢复

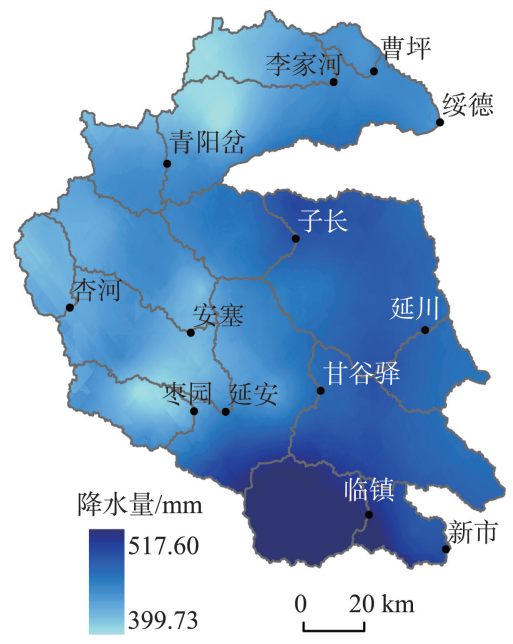

图 3 2006-2011年陕北黄土丘陵沟壑区 年均汛期降水量分布图

Fig.3 Distribution of average annual precipitation of flood season in northern Shaanxi loess hilly-gully region, 2006-2011
以及未来植被的增加提供了基础。在研究区域内, 大理河流域植被覆盖的整体水平低于其他 3 个流 域,但该流域大部分区域植被状况呈现中度改善或 明显改善,说明在植被覆盖状况较差的地区退耕还 林还草的力度较大, 植被覆盖水平得到了有效提 升,这与已有研究结果一致(王朗等, 2010; 白建军 等, 2014)。

\section{2 降水和植被对径流的影响}

为探究降水和植被对径流的影响, 本文利用 13 个子流域 2006-2011 年 5-10月的降水、NDVI、径流 数据分别计算了不同子流域降水一径流、 $N D V I-$ 径流的相关系数、偏相关系数以及 $N D V I$ 一降水的 相关系数(图 5)。

由图 5a 可见, 13 个子流域降水与径流相关系 数介于 $0.58 \sim 0.88$ 之间, 并且均通过了 $P<0.01$ 的 $T$ 检 验 $(P$ 为拒绝原假设的最小显著性水平), 这表明降 水和径流之间具有良好的正相关性。同时,为消除 植被影响, 更好地反映降水和径流间的关系,计算 二者的偏相关系数。结果发现, 降水与径流的偏相 关系数与二者的相关系数相差不大, 并且 $85 \%$ 的子 流域通过了 $P<0.01$ 的 $T$ 检验, 说明降水和径流有显 著的正相关关系, 植被对二者关系的影响较小。由 图 $5 \mathrm{~b}$ 可见, $N D V I$ 与径流的相关系数在 $0.04 \sim 0.59$ 之 间, 并且径流与 $N D V I$ 的偏相关系数与二者的相关 系数差异显著, 说明植被与径流间的关系受降水的 影响较大。对 $N D V I$ 与降水进行相关分析, 结果表

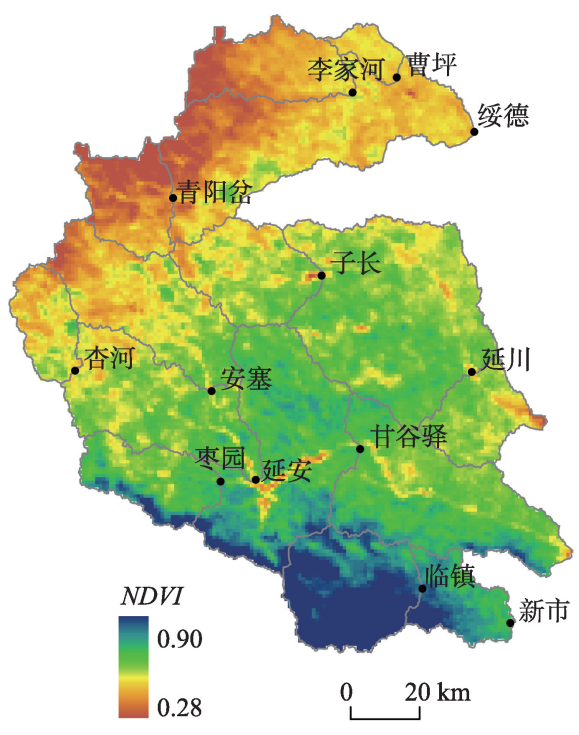

a. 年均最大 $N D V I$

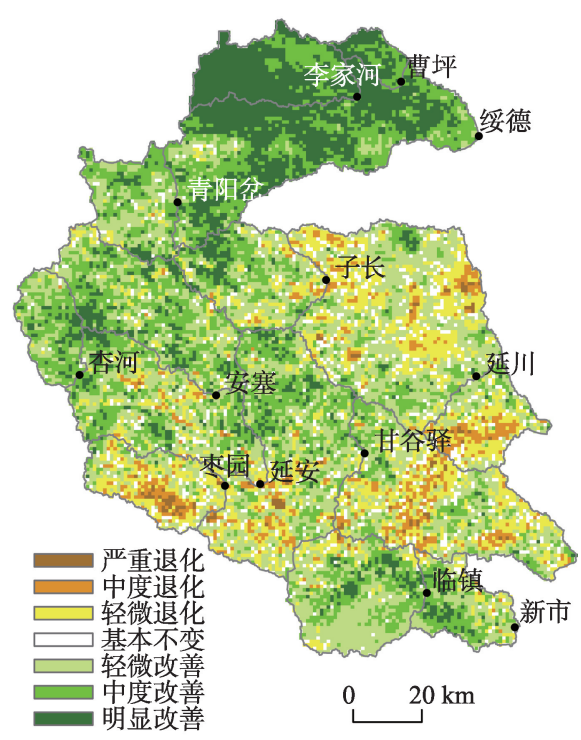

b. 植被变化趋势

图 4 2006-2011 年陕北黄土丘陵沟壑区年均最大 NDVI以及植被变化趋势

Fig.4 Annual maximum NDVI and vegetation change in northern Shaanxi loess hilly-gully region, 2006-2011 

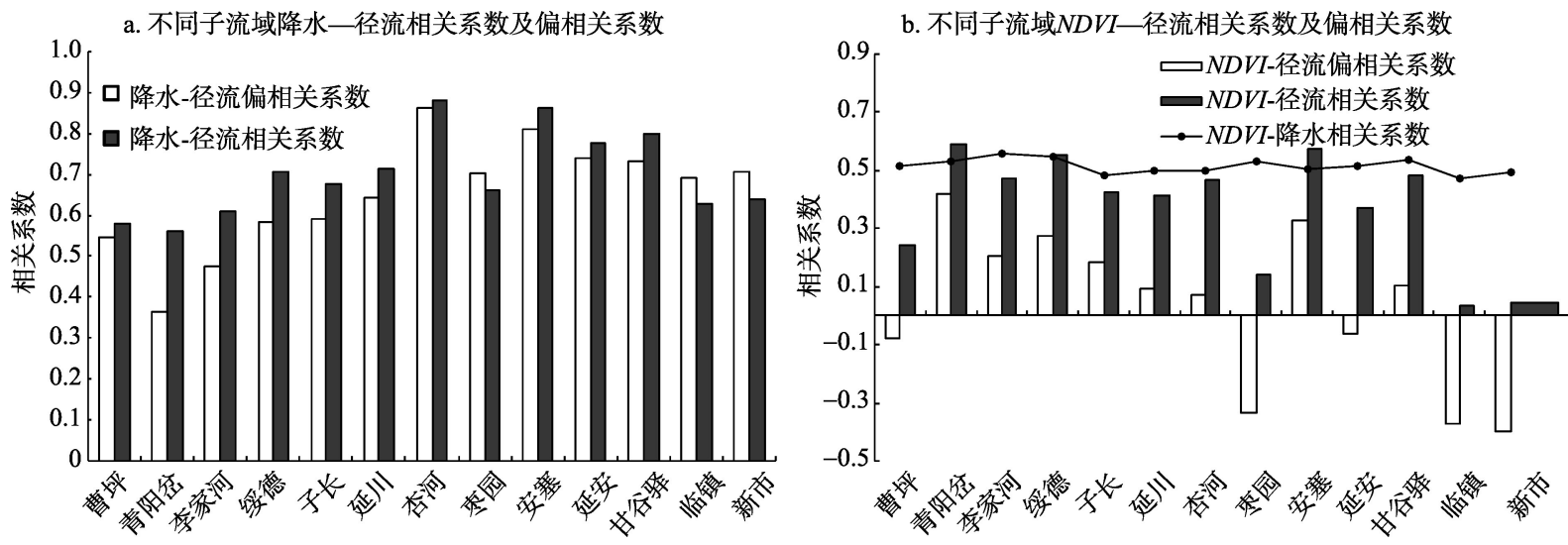

图 5 不同子流域降水一径流、 $N D V I$ 一径流的相关系数、偏相关系数以及 $N D V I$ 一降水的相关系数

Fig.5 Correlation coefficients and partial correlation coefficients of precipitation-runoff and NDVI-runoff and correlation coefficient of NDVI-precipitation in different sub-watersheds

明二者呈现出正相关性, 相关系数在 0.5 左右, 其中 12 个子流域通过了 $P<0.05$ 的 $T$ 检验, 说明降水对植 被的影响较大, 在进行简单相关分析时掩盖了植被 对径流的影响作用。为准确反映 NDVI对径流的影 响, 对二者的偏相关系数进行分析, 发现 13 个子流 域 $N D V I$ 与径流间的正负相关性并不一致,并且所 有的偏相关系数都没有通过 $P<0.05$ 的 $T$ 检验。说 明植被与径流间没有显著的相关性, 二者的关系受 降水等因素的影响较大, 不同的地区二者间的正负 反馈机制有明显差异。

\section{3 降水与 $N D V I$ 对径流影响的尺度效应}

3.3.1 降水对径流影响的尺度效应

降水一径流相关系数可以反映降水对径流的 影响程度。为探究降水对径流影响的尺度效应, 拟 合降水和径流相关系数随子流域面积增加的趋势 图(图 6)。由图 6a 可以看出, 随着子流域面积增加, 降水一径流的相关系数呈增大趋势。但是拟合优 度 $R^{2}$ 仅为 0.14 , 未通过 $P<0.05$ 的 $T$ 检验。

对图 6a 中所得的一元线性回归方程进行残差
分析, 作各流域降水一径流相关系数随流域面积变 化的残差图(图 7)。由图 7 可知, 大部分流域降水一 径流相关系数的残差集中分布于残差等于 0 的直线 (即 $\mathrm{x}$ 轴)附近, 而杏河、安塞两流域降水一径流相关 系数的残差明显偏高, 这两个流域的降水一径流相 关系数相对于其他子流域为异常值。杏河与安塞 子流域均属于延河流域,二者的降水一径流相关系 数分别为 $0.88 、 0.86$,均高于同流域其他 3 个子流 域。杏河和安塞大部分地区的 $N D V I$ 处于较低水平 (图 4a), 两子流域年最大 $N D V I$ 均低于延河流域的 其他 3 个子流域。已有研究表明,植被盖度与地表 径流呈负相关关系(罗伟祥等, 1990; 张光辉等, 1996), 在植被覆盖较低的区域,植被对降水的截留 和缓冲功能降低, 土壤人渗能力下降, 从而使得产 流增加, 降水与径流的相关性增大(Descroix et al, 2001; 韦红波等, 2002; 张建军等, 2008; Wang et al, 2012; Zhang et al, 2014; 张亭亭等, 2014;)。因此杏 河与安塞两个子流域降水与径流的相关系数比延 河流域其他子流域要高。尽管图 6a整体的拟合效
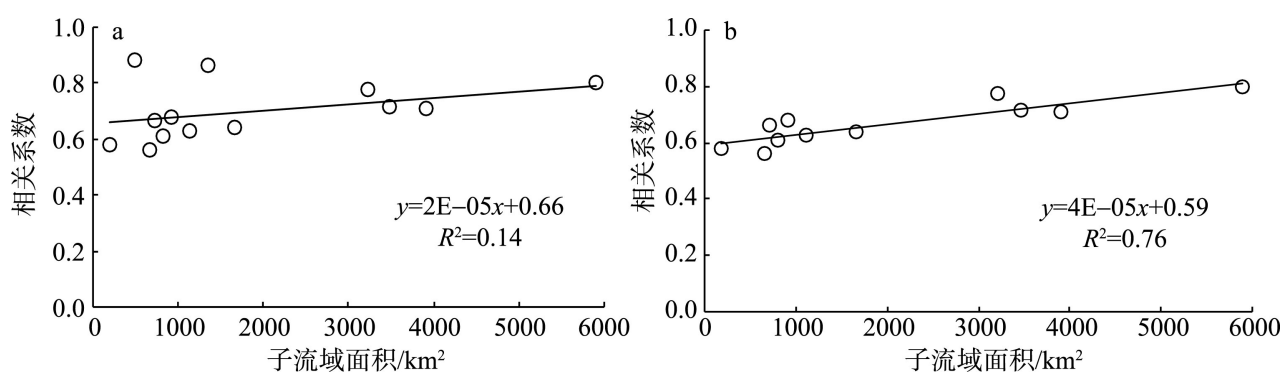

图 6 降水一径流相关系数随子流域面积变化的趋势 (a、全部子流域; $b$ 、剔除异常点后)

Fig.6 Change of correlation coefficients of precipitation and runoff with the area of sub-watersheds (a: all sub-watersheds; b: excluding abnormal points) 
果较低, 但若剔除杏河和安塞这两个异常点之后, 降水一径流相关系数随子流域面积变化的拟合效 果较好, $R^{2}$ 达 0.76 , 通过 $P<0.01$ 的 $T$ 检验(图 $6 \mathrm{~b}$ )。随 着子流域面积的增加, 降水一径流相关系数呈现出 线性增加的趋势。说明在陕北黄土丘陵沟壑区, 随 着子流域面积增大, 降水对径流的影响整体上呈现 出增大的趋势, 这与董晓辉等(2007)得出的结论 一致。

格局一过程一尺度是景观生态学的经典范 式。不同尺度上格局与过程之间相互作用关系不 同, 从而产生一定的尺度依赖性 (Peters et al, 2007)。因此探究产生尺度效应的原因, 需要研究

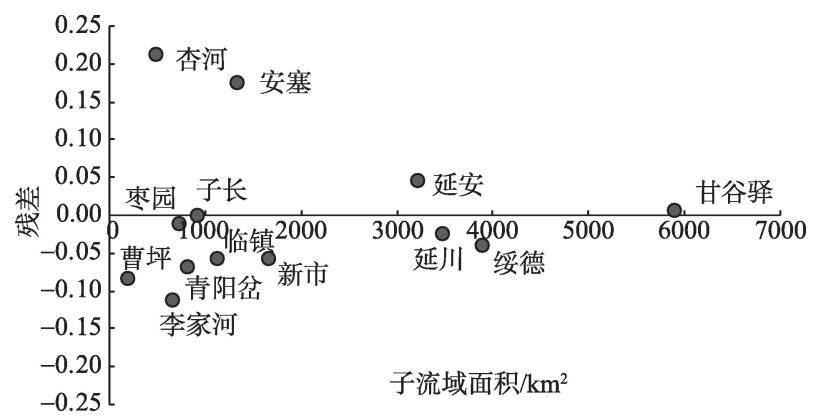

图 7 降水一径流相关系数的残差

Fig.7 Residual error of correlation coefficient of precipitation and runoff
不同尺度上格局和过程的相互作用。在流域尺度， 不同土地利用方式通过影响下垫面的特性进而影 响径流的产生(傅伯杰等, 2003), 而在相同的土地利 用方式下,坡度则是影响水土流失的重要因素(徐 宪立等, 2006)。因此,本文从不同坡度的土地利用 结构分析降水对径流影响的尺度效应。

由于 $15^{\circ}$ 是沟蚀十分剧烈的分界点, $25^{\circ}$ 是退耕 还林的界限(赵牡丹等, 2002), 因此按 $0 \sim 15^{\circ} 、 15^{\circ} \sim$ $25^{\circ} 、 25^{\circ}$ 以上这 3 个坡度级别对 13 个子流域提取坡 度,绘制不同坡度等级土地面积比例随子流域面积 的变化图(图 8)。

随着子流域面积增加, $0^{\circ} \sim 15^{\circ}$ 的土地面积比例 下降, $15^{\circ} \sim 25^{\circ}$ 以及 $25^{\circ}$ 以上的土地面积比例呈上升 趋势。说明随着子流域面积的增大,陡坡土地比例 逐渐增大, 这与陕北黄土丘陵沟壑区破碎的地形状 况有关。陡坡土地利用结构对产流影响较大,运用 2008 年土地利用图对 $15^{\circ}$ 以上的土地利用结构进行 分析。由于在研究的区域内, 森林、草地、农田占绝 大部分 (95\%以上), 因此分析了不同坡度等级森林 (包含灌木)、草地、农田所占比例随子流域面积增大 的变化趋势(图9)。

由图 9 可知, 随着子流域面积增加, $15^{\circ} \sim 25^{\circ}$ 、 $25^{\circ}$ 以上土地利用均呈现出草地比例上升、森林和

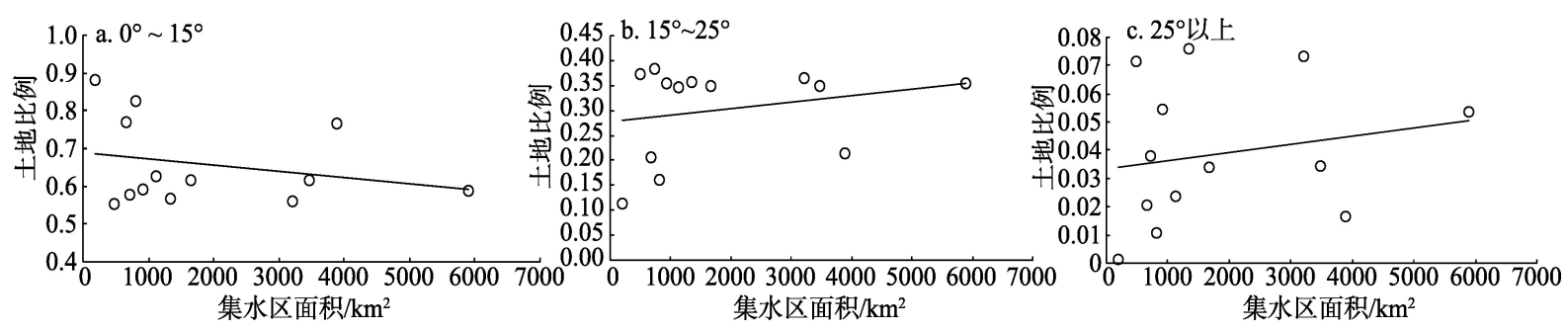

图 8 各坡度土地面积所占比例随子流域面积的变化趋势

Fig.8 Change of area proportionof different slopes with the area of sub-watersheds
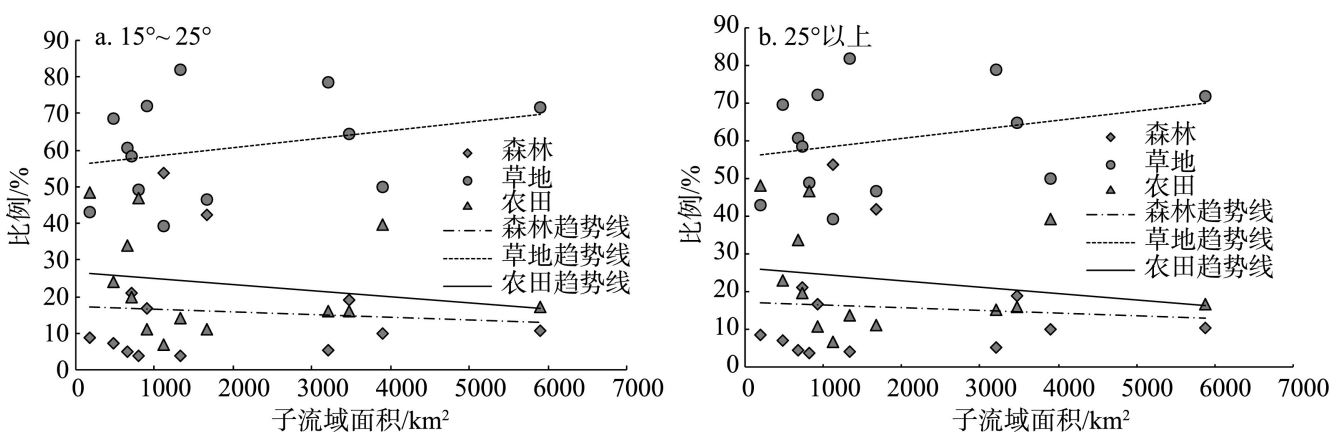

图 9 不同坡度下土地利用类型的面积比例随子流域面积的变化趋势

Fig.9 Changeof area proportion of the three land-use types with the area of sub-watersheds 
农田所占比例下降的趋势。据已有研究, 森林、草 地、农田三种土地利用类型的水源涵养功能依次为 森林>草地 $\approx$ 农田(齐清等, 2005; 何斌等, 2009; 于国 强等, 2010)。草地与农田的面积比例随子流域面 积变化的速率相当, 且两种土地利用类型的水源涵 养功能相差不大, 因此仅从草地和农田变化情况来 看, 对流域生态系统的水源涵养功能影响不大; 而 森林比例的变化是引起尺度效应的主要原因。林 地具有较好的截留功能, 其土壤蓄水能力、枯落物 持水能力高于草地, 且多数林地都具有林一灌一草 或林一草多层次结构, 其下的草本层、枯枝落叶层 和腐殖质层是地表的重要覆盖面和保护层, 能有效 增加降雨人渗, 吸收和阻延地表径流, 改善土壤性 状, 提高土壤的蓄水能力(傅伯杰等, 2002; 于国强 等, 2012; 艾宁等, 2013)。所以, 林地的减少, 降低 了产流过程中植被截留和土壤蓄水的比例, 从而增 强了降水与径流的相关性(孙佳佳等, 2010; 高光耀 等, 2013)。因此, 随子流域面积增大, 具有较高水 源涵养功能的林地比例下降是导致降水与径流的 相关性增强、并形成尺度效应的主要原因。

据已有研究, 植被盖度与地表径流呈负相关关 系。在植被覆盖较高的区域, 植被对降水的截留和 缓冲功能增强, 从而使得产流减少(韦红波等, 2002), 降水与径流的相关性较小。在降水量较少 的条件下, 相对于降水和径流相关性较大的流域, 降水和径流相关性较小的流域产流更少, 植被对水 源的涵养与人类对水源的需求间的冲突更强。由 于草地的水源涵养功能低于林地的水源涵养功能, 但草本植物的地上部分有直接拦沙的作用, 其土壤 保持功能与林地相差不大(于国强等, 2010)。因此, 为权衡水源涵养服务与水供给服务, 在退耕还林还 草的过程中可尝试适当地还草先于还林。因造林 比种草所要求的降水条件高, 人工林地较人工草地 的水分亏缺更为严重, 在水分条件限制的情况下更 容易出现土壤干层和植被退化的现象(郭忠升等, 2003; 杨磊等, 2011; 姚雪玲等, 2012)。本研究区域 的降水梯度较大, 植被生长地带性明显。尤其在降 水量较低的西北部地区, 降水量还不能满足林木可 持续生长的标准(谭勇等, 2006)。同时研究区域内 地形起伏较大, 沟壑纵横, 人工造林由于受到环境 限制, 只宜在水分条件较好的沟道和阴坡适当发展 (谭勇等, 2006); 在坡度较大的地区, 林木成活率较
低, 更适合天然草本群落的生长和自然恢复(胡良 军等, 2004)。因此, 在降水量较小且降水和径流相 关性较小的流域(如李家河、麥园等子流域), 可尝试 还草先于还林, 在陡坡上实施撂荒或者种植一些耗 水低的禾本科草种(Yang et al, 2012), 在确保水土保 持功能的前提下适当增加产流, 兼顾人类对水资源 的需求。

\subsection{2 植被对径流影响的尺度效应}

拟合 $N D V I$ 和径流的相关系数与子流域面积的 趋势线(图 10)。散点图中的点分布比较散乱, $R^{2}$ 为 0.063 , 没有通过 $P<0.05$ 的 $T$ 检验, 拟合效果较差。 对 NDVI一径流相关系数作残差分析, 由图 11 可知, 各流域 $N D V I$ 一径流相关系数的残差成离散分布, 大部分流域的残差绝对值较大, 回归拟合效果不 佳。说明 $N D V I$ 与径流的相关系数随子流域面积变 化的规律性不强。主要是由于植被与径流的关系 较为复杂, 且受降水等因素的影响较大, 各子流域 $N D V I$ 与径流间的相关性并不显著, 因此植被对径 流影响的尺度效应不明显。

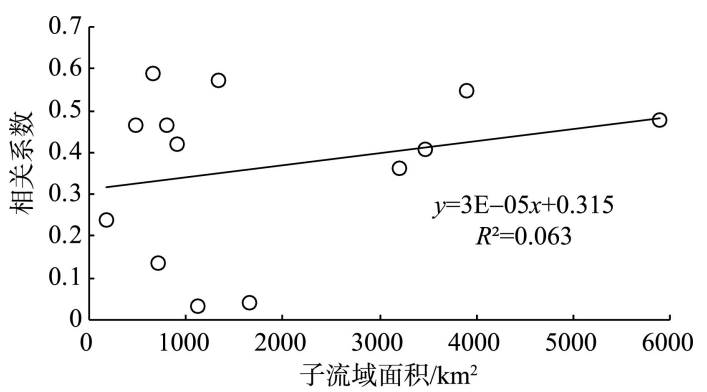

图 $10 \mathrm{NDVI}$ 一径流相关系数随子流域面积的变化趋势

Fig.10 Change of correlation coefficient of NDVI and runoff with the area ofsub-watersheds

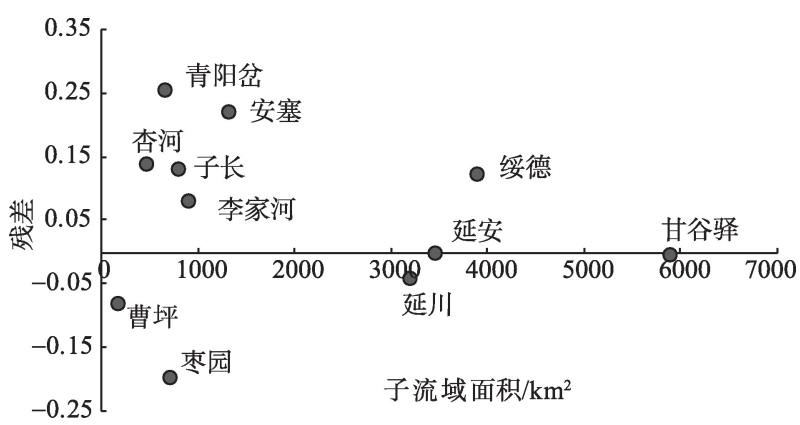

图 $11 N D V I$ 一径流相关系数的残差

Fig.11 Residual error of correlation coefficient of NDVI and runoff 


\section{4 结论}

(1) 2006-2011 年期间, 陕北黄土丘陵沟壑区年 平均汛期降水量整体上呈现由东南向西北逐渐减 少的空间分异特征。退耕还林还草政策调整后, 研 究区内植被恢复效果明显,近 8 成地区植被覆盖状 况得到了改善,尤其是植被覆盖较差的地区植被恢 复更为显著。同时, $15.18 \%$ 的区域植被呈轻微退化 趋势, 一定程度上影响了生态系统服务功能的可持 续性。

（2）降水与径流呈现出显著的正相关性, 而 $N D V I$ 与径流的相关性并不显著。降水对径流的影 响具有明显的尺度效应, 降水与径流的相关性随子 流域面积的增大呈增强趋势。其原因是随着子流 域面积的增大, $15^{\circ}$ 以上土地比例增加, 陡坡植被覆 盖类型趋于均一化, 具有显著截流功能的林地呈现 减少趋势; 而 $N D V I$ 对径流影响的机制较为复杂, 不 具明显的尺度效应。由于草地水源涵养功能低于 林地的水源涵养功能, 但是二者的水土保持功能相 差不大,且造林比种草所要求的水分条件较高。因 此在降水量较少且降水和径流相关性较小的区域, 可以尝试在陡坡上实施撂荒或者种植一些耗水低 的禾本科草种,在确保水土保持功能的前提下适当 增加产流,兼顾人类对水资源的需求。

(3) 本文对降水、植被的变化以及二者对径流 影响的尺度效应进行了分析, 但由于选取的研究时 间段较短,没有考虑气温、蒸发变化对径流的影响 作用。同时,本文侧重于对不同流域尺度降水和植 被对径流影响的作用机制进行探究, 为生态系统权 衡提供一定的理论支撑; 而对生态系统服务功能权 衡和协同机制有待于进一步定量分析, 结合区域可 持续发展和人类生产生活需求, 制定更加合理具体 的土地利用规划方案。

\section{参考文献(References)}

艾宁, 魏天兴, 朱清科. 2013. 陕北黄土高原不同植被类型下 降雨对坡面径流侵蚀产沙的影响[J]. 水土保持学报, 27 (2): 26-30. [Ai N, Wei T X, Zhu Q K. 2013. The effect of rainfall for runoff-erosion-sediment yield under the different vegetation types in Loess Plateau of northern Shaanxi Province[J]. Journal of Soil and Water Conservation, 27 (2): 26-30.]

白建军, 白江涛, 王否. 2014. 2000-2010 年陕北地区植被 NDVI 时空变化及其与区域气候的关系 [J]. 地理科学,
34(7): 882-888. [Bai J J, Bai J T, Wang L. 2014. Spatiotemporal change of vegetation NDVI and its relations with regional climate in northern Shaanxi Province in 2000-2010[J]. Scientia Geographica Sinica, 34(7): 882888.]

陈燕. 2001. 不同空间尺度 DEM 坡度转换图谱研究: 以在黄 土高原的试验为例 [D]. 西安: 西北大学. [Chen Y. 2001 DEM slope transformation maps in different space scale: take experiment in Loess Plateau as an example[D]. Xi'an, China: Northwest University.]

董晓辉, 姚治君, 陈传友. 2007. 黄河源区径流变化及其对降 水的响应 [J]. 资源科学, 29(3): 67-73. [Dong X H, Yao Z J, Chen C Y. 2007. Runoff variation and responses to precipitation in the source regions of the Yellow River[J]. Resources Science, 29(3): 67-73.]

傅伯杰, 陈利顶, 王军, 等. 2003. 土地利用结构与生态过程 [J]. 第四纪研究, 23(3): 247-255. [Fu B J, Chen L D, Wang J, et al. 2003. Land use structure and ecological processes[J]. Quaternary Sciences, 23(3): 247-255.]

傅伯杰, 邱扬, 王军, 等. 2002. 黄土丘陵小流域土地利用变 化对水土流失的影响 [J]. 地理学报, 57(6): 717 - 722 .

[Fu B J, Qiu Y, Wang J, et al. 2002. Effect simulations of land use change on the runoff and erosion for a gully catchment of the loess plateau, China[J]. Acta Geographica Sinica, 57(6): 717 - 722. ]

傅伯杰, 徐延达, 吕一河. 2010. 景观格局与水土流失的尺度 特征与耦合方法 $[\mathrm{J}]$. 地球科学进展, 25(7): 673-681. [Fu B J, Xu Y D, Lv Y H. 2010. Scale characteristics and coupled research of landscape pattern and soil and water loss [J]. Advances in Earth Science, 25(7): 673-681.]

高光耀, 傅伯杰, 吕一河, 等. 2013. 干旱半干旱区坡面覆被 格局的水土流失效应研究进展 [J]. 生态学报, 33(1): 1222. [Gao G Y, Fu B J, Lv Y H, et al. 2013. The effect of land cover pattern on hillslop soil and water loss in the arid and semi-arid region: a review[J]. Acta Ecologica Sinica, 33(1): 12-22.]

郭忠升, 邵明安. 2003. 半干旱区人工林草地土壤旱化与土 壤水分植被承载力 $[\mathrm{J}]$. 生态学报, 23(8): 1640-1647. [Guo Z S, Shao M A. 2003. Soil water carrying capacity of vegetation and soil desiccation in artificial forestry and grassland in semi-arid regions of the Loess Plateau[J]. Acta Ecologica Sinica, 23(8): 1640-1647.]

何斌, 黄承标, 秦武明, 等. 2009. 不同植被恢复类型对土壤 性质和水源涵养功能的影响 [J]. 水土保持学报, 23(2): 71-94. [He B, Huang C B, Qin W M, et al. 2009. Effect of different vegetation restoration types on soil properties and water conservation function[J]. Journal of Soil and Water Conservation, 23(2): 71-94.] 
胡良军, 邵明安, 杨文治. 2004. 黄土高原土壤水分的空间分 异及其与林草布局的关系 [J]. 草业学报, 13(6): 14-20. [Hu L J, Shao M A, Yang W Z. 2004. Relationship between vegetation spatial collocations and soil moisture spatial heterogeneities in the Loess Plateau area[J]. Acta Prataculturae Sinica, 13(6): 14-20.]

李春晖, 杨志峰. 2004. 黄河流域 NDVI 时空变化及其与降 水/径流关系 [J]. 地理研究, 23(6): 753-759. [Li C H, Yang Z F. 2004. Spatio-temporal changes of NDVI and their relations with precipitation and runoff in the Yellow River Basin[J]. Geographical Research, 23(6): 753-759.] 李双双, 延军平, 万佳. 2012. 近 10 年陕甘宁黄土高原区植被 覆盖时空变化特征 [J]. 地理学报, 67(7): 960-970. [Li S S, Yan J P, Wan J. 2012. The spatial-temporal changes of vegetation restoration on Loess Plateau in Shaanxi-GansuNingxia region[J]. Acta Geographica Sinica, 67(7): 960970.]

刘海猛, 石培基, 周俊菊, 等. 2013. 石羊河中游径流损耗特 征及其影响因素 [J]. 地理科学进展, 32(1): 87-94. [Liu H M, Shi P J, Zhou J J, et al. 2013. Characteristics and influencing factors of runoff consumption in the midstream of Shiyang river[J]. Progress in Geography, 32(1): 87-94.] 刘晓燕, 刘昌明, 杨胜天, 等. 2014. 基于遥感的黄土高原林 草植被变化对河川径流的影响分析 [J]. 地理学报, 69 (11): 1595-1603. [Liu X Y, Liu C M, Yang S T, et al. 2014. Influences of shrubs-herbs-arbor vegetation coverage on the runoff based on the remote sensing data in Loess Plateau[J]. Acta Geographica Sinica, 69(11): 15951603.]

刘欣欣, 陈楠, 朱海金. 2013. 基于 DEM 的坡度精度研究 [J]. 人民黄河, 35(2): 131-133. [Liu X X, Chen N, Zhu H J. 2013. Study of the accuracy of slop based on grid digital elevation model (DEM) [J]. Yellow River, 35(2): 131133.]

刘引鸽. 2007. 陕北黄土高原降水的变化趋势分析 [J]. 干旱 区研究, 24(1): 49-55. [Liu Y G. 2007. Analysis on the change trend of precipitation in north Shaanxi province in the Loess Plateau[J]. Arid Zone Research, 24(1): 49-55.]

罗伟祥, 白立强, 宋西德, 等. 1990. 不同覆盖度林地和草地 的径流量与冲刷量 [J]. 水土保持学报, 4(1): 30-35. [Luo W Q, Bai L Q, Song X D, et al. 1990. Runoff and scouring amount in forest and grass land with different cover rate[J]. Acta Conservations Soil et Aquae Sinica, 4(1): 3035.]

吕一河, 傅伯杰. 2001. 生态学中的尺度及尺度转换方法 [J]. 生态学报, 21(12): 2096-2105. [Lv Y H, Fu B J. 2001. Ecological scale and scaling[J]. Acta Ecologica Sinica, 21
(12): 2096-2105.]

马明国, 王建, 王雪梅. 2006. 基于遥感的植被年际变化及其 与气候关系研究进展 [J]. 遥感学报, 10(3): 421-431. [Ma M G, Wang J, Wang X M. 2006. Advance in the Inter-annual variability of vegetation and its relation to climate based on Remote Sensing[J]. Journal of Remote Sensing, 10(3): 421-431.]

綦俊谕, 蔡强国, 蔡乐, 等. 2011. 岔巴沟、大理河与无定河水 土保持减水减沙作用的尺度效应 [J]. 地理科学进展, 30 (1): 95-102. [Qi J Y, Cai Q G, Cai L, et al. 2011. Scale effect of runoff and sediment reduction effects of soil and water conservation measures in Chabagou, Dalihe and Wudinghe basins[J]. Progress in Geography, 30(1): 95102.]

齐清, 李传荣, 许景伟, 等. 2005. 沙质海岸不同植被类型土 壤水源涵养功能的研究 [J]. 水土保持学报, 19(6): 102105. [Qi Q, Li C R, Xu J W, et al. 2005. Study on water conservation capacity of different vegetation types in sandy sea coastal area[J]. Journal of Soil and Water Conservation, 19(6): 102-105.]

邱扬, 傅伯杰. 2004. 异质景观中水土流失的空间变异与尺 度变异 [J]. 生态学报, 24(2): 330-337. [Qiu Y, Fu B J. 2004. Spatial variation and scale variation in soil and water loss in heterogeneous landscape: a review[J]. Acta Ecologica Sinica, 24(2): 330-337.]

孙佳佳, 于东升,史学正, 等. 2010. 植被叶面积指数与覆盖度 定量表征红壤区土壤侵蚀关系的对比研究 $[\mathrm{J}]$. 土壤学 报, 47(6): 1060-1066. [Sun J J, Yu D S, Shi X Z, et al. 2010. Comparison of between LAI and VFC in relationship with soil erosion in the red soil hilly region of South China[J]. Acta Pedologica Sinica, 47(6): 1060-1066.]

孙睿, 刘昌明, 朱启疆. 2001. 黄河流域植被覆盖度动态变化 与降水的关系 [J]. 地理学报, 56(6): 667-672. [Sun R, Liu C M, Zhu Q J. 2001. Relationship between the fractional vegetation cover change and rainfall in the Yellow River Basin[J]. Acta Geographica Sinica, 56(6): 667-672.] 汤国安, 杨勤科, 张勇, 等. 2001. 不同比例尺 DEM 提取地面 坡度的精度研究: 以在黄土丘陵沟壑区的试验为例 $[\mathrm{J}]$. 水土保持通报, 21(1): 53-56. [Tang G A, Yang Q K, Zhang Y, et al. 2001. Research on accuracy of slope derived from DEMs of different map scales[J]. Bulletin of Soil and Water Conservation, 21(1): 53-56.]

谭勇, 王长如, 梁宗锁, 等. 2006. 黄土高原半干早区林草植 被建设措施 [J]. 草业学报, 15(4): 4-11. [Tan Y, Wang C R, Liang Z S, et al. 2006. Measures for forest and grass vegetation construction in semi-acid areas on the Loess Plateau[J]. Acta Prataculturae Sinica, 15(4): 4-11.] 
王宏, 李晓兵, 李霞, 等. 2007. 基于 NOAA NDVI 和 MSAVI 研究中国北方植被生长季变化 [J]. 生态学报, 27(2): 504-515. [Wang H, Li X B, Li X, et al. 2007. The variability of vegetation growing season in the northern China based on NOAA NDVI and MSAVI from 1982 to 1999 [J]. Acta Ecologica Sinca, 27(2): 504-515.]

王朗, 傅伯杰, 吕一河, 等. 2010. 生态恢复背景下陕北地区植 被覆盖的时空变化 [J]. 应用生态学报, 21(8): 2109-2116. [Wang L, Fu B J, Lv Y H, et al. 2010. Spatio-temporal variations of vegetation cover in northern Shaanxi Province under the back ground of ecological restoration[J]. Chinese Journal of Applied Ecology, 21(8): 2109-2116.]

王麒翔, 范晓辉, 王孟本. 2011. 近 50 年黄土高原地区降水时 空变化特征 [J]. 生态学报, 31(19): 5512-5523. [Wang Q X, Fan X H, Wang M B. 2011. Precipitation trends during 1961-2010 in the Loess Plateau region of China[J]. Acta Ecologica Sinica, 31(19): 5512-5523.]

王闰平, 陈凯. 2006. 中国退耕还林还草现状及问题分析 [J]. 水土保持研究, 13(5): 188-192. [Wang R P, Chen K. 2006. Analysis of the situation and problems in reverting farmland to forests and grassland in China[J]. Research of Soil and Water Conservation, 13(5): 188-192.]

王毅荣. 2005. 黄土高原植被生长期旱涝对全球气候变化响 应 [J]. 干旱区地理, 28(2): 161-166. [Wang Y R. 2005. Response of droughts or water loggings in the Loess Plateau in China to global climate change[J]. AridZone Research, 28(2): 161-166.]

韦红波, 李锐, 杨勤科. 2002. 我国植被水土保持功能研究进 展 [J]. 植物生态学报, 26(4): 489-496. [Wei H B, Li R, Yang Q K. 2002. Research advances of vegetation effect on soil and water conservation in China[J]. Acta Phytoecologica Sinica, 26(4): 489-496.]

邬建国. 2000. 景观生态学概念与理论 [J]. 生态学杂志, 19 (1): 42-52. [Wu J G. 2000. Landscape ecology-concepts and theories[J]. Chinese Journal of Ecology, 19(1): 4252.]

信忠保, 余新晓, 甘敬, 等. 2009. 黄河中游河龙区间植被覆 盖变化与径流输沙关系研究 [J]. 北京林业大学学报, 31 (5): 1-7. [Xin Z B, Yu X X, Gan J, et al. 2009. Vegetation restoration and its effects on runoff and sediment yield in Hekouzhen- Longmen section of the middle reaches of Yellow River[J]. Journal of Beijing Forestry University, 31(5): 1-7.]

徐宪立, 马克明, 傅伯杰, 等. 2006. 植被与水土流失关系研 究进展 [J]. 生态学报, 26(9): 3137-3143. [Xu X L, Ma K M, Fu B J, et al. 2006. Research review of the relationship between vegetation and soil loss[J]. Acta Ecologica
Sinica, 26(9): 3137-3143.]

杨碟, 卫伟, 莫保儒, 等. 2011. 半干旱黄土丘陵区不同人工 植被恢复土壤水分的相对亏缺 [J]. 生态学报, 31(11): 3060-3068. [Yang L, Wei W, Mo B R, et al. 2011. Soil water deficit under different artificial vegetation restoration in the semi-arid hilly region of the Loess Plateau[J]. Acta Ecologica Sinica, 31(11): 3060-3068.]

姚雪玲, 傅伯杰, 吕一河. 2012. 黄土丘陵沟壑区坡面尺度土 壤水分空间变异及影响因子 [J]. 生态学报, 32(16): 4961-4968. [Yao X L, Fu B J, Lv Y H. 2012. Spatial patterns of soil moisture at transect scale in the Loess Plateau of China[J]. Acta Ecologica Sinica, 32(16): 49614968.]

易浪, 任志远, 张翀, 等. 2014. 黄土高原植被覆盖变化与气 候和人类活动的关系 $[\mathrm{J}]$. 资源科学, 36(1): 166-174. [Yi L, Ren Z Y, Zhang C, et al. 2014. Vegetation cover, climate and human activities on the Loess Plateau[J]. Resources Science, 36(1): 166-174.]

于国强, 李占斌, 李鹏, 等. 2010. 不同植被类型的坡面径流 侵蚀产沙试验研究 [J]. 水科学进展, 21(5): 593-599. [Yu G Q, Li Z B, Li P, et al. 2010. Effects of vegetation types on hillslope runoff- erosion and sediment yield[J]. Advances in Water Science, 21(5): 593-599.]

于国强, 李占斌, 裴亮, 等. 2012. 不同植被类型下坡面径流 侵蚀产沙差异性 [J]. 水土保持学报, 26(1): 1-5, 11. [Yu G Q, Li Z B, Pei L, et al. 2012. Difference of runoff-erosion-sediment yield under different vegetation type[J]. Journal of Soil and Water Conservation, 26(1): 1-5, 11.]

张宝庆, 吴普特, 赵西宁. 2011. 近 30a 黄土高原植被覆盖时 空演变监测与分析 [J]. 农业工程学报, 27(4): 287-293. [Zhang B Q, Wu P T, Zhao X N. 2011. Detecting and analysis of spatial and temporal variation of vegetation cover in the Loess Plateau during 1982-2009[J]. Transactions of the Chinese Society of Agricultural Engineering, 27(4): 287-293.]

张光辉, 梁一民. 1996. 植被盖度对水土保持功效影响的研 究综述 [J]. 水土保持研究, 3(2): 104-110. [Zhang G H, Liang Y M. 1996. A summary of impact of vegetation coverage on soil and water conservation benefit[J]. Research of Soil and Water Conservation, 3(2): 104-110.] 张建军, 纳否, 董煌标, 等. 2008. 黄土高原不同植被覆盖对流 域水文的影响 [J]. 生态学报, 28(8): 3597-3605. [Zhang J J, Na L, Dong H B, et al. 2008. Hydrologyical response to changes in vegetation covers of small watersheds on the Loess Plateau[J]. Acta Ecologica Sinica, 28(8): $3597-$ 3605.]

张亭亭, 张建军, 郭敏杰, 等. 2014. 北洛河流域不同地貌和 
植被类型区径流演变特征及控制因素 [J]. 水土保持学 报, 28 (4): 78-84. [Zhang T T, Zhang J J, Guo M J, et al. 2014. Trend of streamflow and its controlling factor under the regional vegetation restoration in Beiluo river ba$\sin [\mathrm{J}]$. Journal of Soil and Water Conservation, 28 (4): 7884.]

张文帅. 2014. 陕甘宁黄土高原区 NDVI变化及其在土地利 用变化检测中的适宜性[D]. 杨凌: 中国科学院大学. [Zhang W S. 2014. NDVI change and its suitability in land use change detection on Loess Plateau in Shaan-GanNing region[D]. Yangling, China: University of Chinese Academy of Sciences.]

张志强, 王盛萍, 孙阁, 等. 2006. 流域径流泥沙对多尺度植 被变化响应研究进展 [J]. 生态学报, 26(7): 2356-2364. [Zhang Z Q, Wang S P, Sun G, et al. 2006. Runoff and sediment yield response to vegetation change at multiple scales: a review[J]. Acta Ecologica Sinica, 26(7): 23562364.]

赵牡丹, 汤国安, 陈正江, 等. 2002. 黄土丘陵沟壑区不同坡 度分级系统及地面坡谱对比 [J]. 水土保持通报, 22(4): 33-36. [Zhao M D, Tang G A, Chen Z J, et al. 2002. Slope classification systems and their slope spectrum in hill and gully area of the Loess Plateau[J]. Bulletin of Soil and Water Conservation, 22(4): 33-36.]

赵文武, 傅伯杰, 陈利顶. 2002. 尺度推绎研究中的几点基本 问题 [J]. 地球科学进展, 17(6): 905-911. [Zhao W W, Fu B J, Chen L D. 2002. Some fundamental issues in scaling [J]. Advances in Earth Science, 17(6): 905-911.]

赵文武, 傅伯杰, 陈利顶, 等. 2004. 黄土丘陵沟壑区集水区 尺度土地利用格局变化的水土流失效应 $[\mathrm{J}]$. 生态学报, 24(7): 1358-1364. [Zhao W W, Fu B J, Chen L D, et al. 2004. Effects of land-use pattern change on soil and water loss at the catchment scale in the hilly and gully area of the loess plateau of China[J]. Acta Ecologica Sinica, 24 (7): 1358-1364. ]

Appels W M, Bogaart P W, Van der Zee S E A T M. 2011. Influence of spatial variations of microtopography and infiltration on surface runoff and field scale hydrological connectivity[J]. Advances in Water Resources, 34(2): 303313.

Bi H X, Liu B, Wu J, et al. 2009. Effects of precipitation and landuse on runoff during the past 50 years in a typical watershed in Loess Plateau, China[J]. International Journal of Sediment Research, 24(3): 352-364.

Chang H J, Jung I W. 2010. Spatial and temporal changes in runoff caused by climate change in a complex large river basin in Oregon[J]. Journal of Hydrology, 388(3-4):
186-207.

Chen H S, Shao M A, Li Y Y. 2008. Soil desiccation in the Loess Plateau of China[J]. Geoderma, 143(1-2): 91-100.

Descroix L, Viramontes D, Vauclin M, et al. 2001. Influence of soil surface features and vegetation on runoff and erosion in the Western Sierra Madre (Durango, Northwest Mexico)[J]. Catena, 43(2): 115-135.

Dungan J L, Perry J N, Dale M R T, et al. 2002. A balanced view of scale in spatial statistical analysis[J]. Ecography, 25(5): 626-640.

Hammad A H A, BØrresen T, Haugen L E. 2006. Effects of rain characteristics and terracing on runoff and erosion under the Mediterranean[J]. Soil and Tillage Research, 87 (1): 39-47.

Huza J, Teuling A J, Braud I, et al. 2014. Precipitation, soil moisture and runoff variability in a small river catchment (Ardèche, France) during HyMeX Special Observation Period 1[J]. Journal of Hydrology, 516 330-342.

Kim J W, Onda Y, Kim M S, et al. 2014. Plot-scale study of surface runoff on well-covered forest doors under different canopy species[J]. Quaternary International, 344: 75-85.

Kirkby M J, Bracken L J, Shannon J. 2005. The influence of rainfall distribution and morphological factors on runoff delivery from dryland catchments in SE Spain[J]. Catena, 62(2-3): 136-156.

Lei H M, Yang D W, Huang M Y. 2014. Impacts of climate change and vegetation dynamics on runoff in the mountainous region of the Haihe River basin in the past five decades[J]. Journal of Hydrology, 511: 786-799.

Mao D H, Wang Z M, Luo L, et al. 2012. Integrating AVHRR and MODIS data to monitor NDVI changes and their relationships with climatic parameters in Northeast China[J]. International Journal of Applied Earth Observation and Geoinformation, 18: 528-536.

Mayor Á G, Bautista S, Bellot J. 2011. Scale-dependent variation in runoff and sediment yield in a semiarid Mediterranean catchment[J]. Journal of Hydrology, 397(1-2): 128-135.

Onema J M K, Taigbenu A E. 2009. NDVI-rainfall relationship in the Semliki watershed of the equatorial Nile[J]. Physics and Chemistry of the Earth, Parts A/B/C, 34(1316): 711-721.

Peters D P C, Bestelmeyer B T, Turner M G. 2007. Cross-scale interactions and changing pattern- process relationships: consequences for system dynamics[J]. Ecosystems, 10 (5): 790-796.

Shi H, Shao M A. 2000. Soil and water loss from the Loess Plateau in China[J]. Journal of Arid Environments, 45(1): 
9-20.

Stow D, Daeschner S, Hope A, et al. 2003. Variability of the seasonally integrated normalized difference vegetation index across the north slope of Alaska in the 1990s[J]. International Journal of Remote Sensing, 24(5): 1111-1117.

Wang G X, Liu G S, Li C J. 2012. Effects of changes in alpine grassland vegetation cover on hillslope hydrological processes in a permafrost watershed[J]. Journal of Hydrology, 444-445: 22-33.

Wu J G. 2004. Effects of changing scale on landscape pattern analysis: scaling relations[J]. Landscape Ecology, 19(2):
125-138.

Yang L, Wei W, Chen L D, et al. 2012. Response of deep soil moisture to land use and afforestation in the semi- arid Loess Plateau, China[J]. Journal of Hydrology, 475: 111-122.

Zhang X, Yu G Q, Li Z B, et al. 2014. Experimental study on slope runoff, erosion and sediment under different vegetation types[J]. Water Resources Management, 28(9): 2415-2433.

Zhao X N, Huang J, Wu P T, et al. 2014. The dynamic effects of pastures and crop on runoff and sediments reduction at loess slopes under simulated rainfall conditions $[\mathrm{J}]$. Catena, 119: 1-7.

\title{
Scale effect of the impact on runoff of variations in precipitation/vegetation : taking northern Shaanxi loess hilly-gully region as an example
}

\author{
DING Jingyi ${ }^{1}$, ZHAO Wenwu ${ }^{1 *}$, WANG Jun ${ }^{2}$, FANG Xuening ${ }^{1}$ \\ (1. College of Resources and Technology, State Key Laboratory of Earth Surface Processes and Resource Ecology, \\ Beijing Normal University, Beijing 100875, China; 2. Key Laboratory of Land Consolidation and Rehabilitation, \\ Ministry of Land and Resources, Beijing 100035, China)
}

\begin{abstract}
Water conservation capability of the loess plateau increased significantly since the Grain for Green project started. At the same time, the amount of runoff significantly reduced, resulting in the question of how to balance the water conservation needs and the need for water supply in the region. In order to explore causes of the runoff reduction and provide support for balancing different needs for water at different scales, the variation of precipitation and vegetation as well as the scale effect of its impact on runoff in northern Shaanxi loess hillygully region during 2006 to 2011 were examined. The results show that: Precipitation of flood season gradually reduced from southeast to northwest in the study area. During the research period, vegetation restored significantly, nearly $80 \%$ of vegetated area was improved, especially in areas with poor vegetation conditions. Precipitation and runoff had significant positive correlation. With the increase of sub- watershed area,the correlation of precipitation and runoff increased, which shows a clear scale effect. The main reason was that land use structure above $15^{\circ}$ of slope changed along with the spatial scale-vegetation types at steep slope tended to be homogenous and forest that has significant water conservation function decreased along with the increase in sub- watershed area. The correlation between NDVI and runoff was neither significant nor forming a clear relationship with the area of sub-watersheds, therefore the scale effect of vegetation influence on runoff was not obvious.
\end{abstract}

Key words: NDVI; precipitation; runoff; scale effect; tradeoff; loess hilly-gully region 